Acta vet. scand. $1981,22,501-516$.

From the National Veterinary Institute, the Norwegian Veterinary College, Oslo, the Agricultural University of Norway, Aas, and the Department of Ophtalmology, University of Florida, College of Medicine, Gainesville, Florida, USA.

\title{
TOXIC AND CARCINOGENIC EFFECTS OF DIMETHYLNITROSAMINE (DMNA) IN THE BLUE FOX (ALOPEX LAGOPUS)
}

\author{
By \\ Nils Koppang, Arne Helgebostad, Donald Armstrong \\ and Hans Rimeslåtten
}

KOPPANG, NILS, ARNE HELGEBOSTAD, DONALD ARMSTRONG and HANS RIMESLATTEN: Toxic and carcinogenic effects of dimethylnitrosamine (DMNA) in the blue fox (Alopex lagopus). Acta vet. scand. 1981, 22, 501-516. - Single doses of DMNA from 8 to $15 \mathrm{mg} / \mathrm{kg}$ body weight (B.W.) were given in the feed, by stomach tube or by subcutaneous application to 37 foxes. The course and intensity of the disease was not influenced by the application route, but was directly related to the amount of DMNA given per $\mathrm{kg}$ body weight, and caused hemorrhagic centrolobular liver necrosis and acute vessel changes especially in the hepatic vein system. The possibility of liver regeneration after a single DMNA exposure depends on the degree of damage in the hepatic vein system. Some animals can recover from the acute disease caused by DMNA. But if the hepatic vessel changes are enough pronounced, progressive changes occur in the hepatic vein system leading to liver cirrhosis.

The observation period of the foxes after a single exposure was from 13 to 380 days. $L D_{50}$ should not be determined after a surviving time of 3 days but rather after 4 weeks. In our material $L_{50}$ was $10 \mathrm{mg}$ DMNA/kg B.W.

In an experiment over a longer period of time 18 foxes divided into 3 groups were given 2 weekly doses of DMNA in food. They were treated with daily estimated doses of $1.0,0.2$ and $0.1 \mathrm{mg}$ DMNA/ $\mathrm{kg}$ B.W., respectively. The foxes in Groups 1 and 2 developed ascites, jaundice and liver failure after intake of $45-70 \mathrm{mg} D M N A / \mathrm{kg} \mathrm{B}$.W. The foxes in Group 1 treated with $1 \mathrm{mg} \mathrm{DMNA} / \mathrm{kg}$ B.W. showed centrolobular hemorrhagic liver necrosis and productive vessel changes in the hepatic vein system. The second group given $0.2 \mathrm{mg}$ DMNA $/ \mathrm{kg}$ B.W. developed hemorrhagic centrolobular necrosis which healed with fibrosis leading to cirrhosis and chronic occlusion in many of the hepatic veins. In addition noduli of chondroid lamellae and foci of hematopoietic tissue and early stages of hemagiomatous liver tumors were found in the liver.

The group expased with $0.1 \mathrm{mg}$ DMNA/kg B.W./day did not develop hemorrhagic centrolobular liver necrosis, but thickening in the walls of the hepatic veins. After more than $3 \frac{1}{2}$ years of exposure multiple hemangiosarcomae were growing out from the changed vessel walls. 
In an experiment over a shorter time period with daily exposure of DMNA doses in the feed below $0.15 \mathrm{mg} / \mathrm{kg} \mathrm{B}$.W., all the foxes were completely healthy and only some showed beginning changes in the hepatic vein walls.

Hematomae were often seen in foxes dying after a single DMNA dose. One fox treated with $0.1 \mathrm{mg} D M N A / \mathrm{kg} \mathrm{B}$.W. died of brain bleeding after 220 days of treatment. Chronic vessel changes were found in the heart and kidneys of the DMNA treated foxes. These results emphasize the fact that DMNA gives vessel changes of a more general nature.

dimethylnitrosamine; blue fox; occlusive vessel changes; hemangiosarcoma; hepatocarcinoma.

The first documentation of the toxic nature of dimethylnitrosamine (DMNA) was recorded in the United States in 1937 (Freund). This report involved an industrial accident in which 2 workers were exposed to DMNA vapor and developed liver failure which was fatal in 1 of the cases. In order to demonstrate the mode of action of DMNA, Freund exposed a dog to DMNA vapor for $30 \mathrm{~min}$. This resulted in convulsions and death $18 \mathrm{~h}$ after exposure. The liver showed necrosis and uniformly distributed hemorrhages around the central veins.

Barnes \& Magee (1954) described a similar industrial accident about 20 years later in Great Britain and of the 3 workers they studied, 1 died while the other 2 developed cirrhosis. Others have subsequently described the toxicity of this agent in a variety of animals (O'Leary et al. 1955, Jacobson et al. 1955). The carcinogenic effect of DMNA was first shown by Magee \& Barnes (1956) and has since been demonstrated in a number of investigations (Magee \& Barnes 1967, Druckrey et al. 1967).

From 1957 to 1962, an epidemic of severe liver disease in fur animals occurred in Norway, which proved to be the result of toxic herring meal in the animals diet (Koppang 1962, 1966, Koppang \& Helgebostad 1962, 1966). The toxic agent appeared to be DMNA (Aldal 1964, Ender et al. 1964, Sakshaug et al. 1965). During processing, especially during the drying process when open air drying is used, DMNA can be formed by the interaction between nitrites used as preservatives and the naturally occurring trimethylamine oxide in fish. Even without use of sodium nitrites as a preservative DMNA can be formed during the open air drying process. The $\mathrm{N}$-nitrosation product may then come from the combustion of oil (Koppang 1974 a) or from the heated air. By high nitrite content the reaction between nitrite and amines can continue during storage of the fish meal (Koppang 
$1974 \mathrm{~b}, \mathrm{c})$. At the time our first experiments with blue- and silver foxes were performed (Koppang \& Helgebostad 1962, 1966) methods for measuring DMNA in fish meal had not been worked out. We now report the $\mathrm{LD}_{50}$ and the levels of DMNA which causes liver intoxication or tumors in the blue fox using pure DMNA. In another experiment, the effects of small daily amounts of DMNA occurring in specially prepared fish meal was examined.

\section{MATERIALS AND METHODS}

The first 2 experiments were carried out at the Government Research Farm for Fur Bearing Animals of the Veterinary College of Norway using blue foxes obtained from the Research farm standard breed. The number of animals used and the doses administered are given in Table 1. Control and experimental animals were housed together and fed the same basic diet. Pure DMNA (British Drug House, Ltd.) was administered to the

T a b l e 1. Dosages of dimethylnitrosamine (DMNA) to foxes.

\begin{tabular}{lll}
\hline Method of administration & Number of foxes & DMNA (mg/kg B.w.) \\
\hline
\end{tabular}

I. Single dose
A) In feed
B) Subcutaneously
C) By stomach tube

3
26
8
18
$12-15$
$8-14$
$8-15$
II. Twice weekly in feed
18
$0.35-3.5$

experimental animals from a $0.35 \%$ or $1 \%$ stock solution dissolved in arachis oil. The stock solution was added to the food, administered by stomach tube, or given subcutaneously in the caudoscapular region. Animals in Experiment I received a single dose of DMNA whereas those in Experiment II received DMNA in their feed twice a week for various periods of time.

The third experiment was performed at the Agricultural University of Norway. Blue fox puppies at approximately 72 days of age were devided into 5 groups, each group consisting of 11 females and 9 males. Two groups were given the basic diet, supplemented with meal prepared from capelin. The 3 other groups were given another source of protein from white fish (low fat) which was added to the basic diet and served as the control groups for those receiving the capelin produced fish meal. All groups 
were kept under identical conditions. After 120 experimental days the foxes were skinned for commercial use. The capelin used in the experimental fish meal contained $50 \mathrm{mg}$ trimethylamine oxide (TMAO)/100 $\mathrm{g}$ of fresh weight (Table 2). The capelin were used to prepare 2 batches of meal, 1 without preservative (Group 1). The other batch was preserved with $920 \mathrm{~g}$ of sodium benzoate and $920 \mathrm{ml}$ formaldehyde per hl (Group 2). These two different "herring meals" contained $2.4 \mathrm{mg}$ or $7.2 \mathrm{mg}$ of DMNA/kg (Table 2). The fish meals were analyzed for DMNA by the polarographic method of Lydersen \& Nagy (1967). The control meals of white fish were selected because they were low in DMNA. The foxes were weighed at regular intervals throughout the experiments in order to calculate exposure and intake of DMNA.

T a b l e 2. Experiment III. Preservation, time of storage and trimethylamine oxide (TMAO) content of capelin before processing and the dimethylnitrosamine (DMNA) content of fish meal used in groups 1 and 2.

\begin{tabular}{cccc}
\hline Preservative $^{*}$ & $\begin{array}{c}\text { Days of storage } \\
\text { before processing }\end{array}$ & $\begin{array}{c}\text { TMAO by processing } \\
(\mathrm{mg} \text { } / 100 \mathrm{~g})\end{array}$ & $\begin{array}{c}\text { DMNA (mg/kg } \\
\text { fish meal) }\end{array}$ \\
\hline $0+0$ & 0 & 50 & 2.4 \\
$920+920$ & 11 & 50 & 7.2 \\
\hline
\end{tabular}

* Sodium benzoate $(\mathrm{g})+$ formaldehyde $(\mathrm{ml}) / \mathrm{hl}$ capelin.

At various intervals, blood samples from Experiments I and II were analyzed for SGOT and SGPT, total serum protein, albumin and globulin, bilirubin, and non-protein nitrogen (NPN). All animals were autopsied, whether they died or were sacrificed. Tissues were routinely examined by fixing tissues in $10 \%$ buffered formalin, and embedding in paraffin. Sections were stained with Hematoxylin Eosin (H.E.), Weigert's resorcin fuchsin-Van Gieson (V.G. El.), a trichrome method, or Wilders reticulin impregnation, as previously described (Koppang 1964).

\section{RESULTS}

Experiment I. Foxes exposed to a single dose of DMNA

a) Clin i c l c o u rse. Foxes showed great variation in survival time after exposure to DMNA even when they received the same dose (Table 3 ). This variation was not dependent upon the 
Nils Koppang et al.: Toxic and Carcinogenic Effects of Dimcthylnitrosamine (DMNA) in the Blue Fox (Alopex lagopus).

F ig u r e 1. Liver from a male fox given a single dose of $14 \mathrm{mg}$ of DMNA/kg B.W. The fox died 10 days later. Centrolobular areas filled with blood and in the same area, necrotic liver cells have been removed by phagocytosis (N). H.E., $70 \times$.

F i g u re 2. Liver from the same fox as in Fig. 1 showing a hepatic vein ( $\mathrm{Vh}$ ) with partial destruction of the endothelial layer, thickning of the wall, infiltration of inflammatory cells and erythrocytes. The elastic tissue in the tunica adventitia is separated and broken. Liver cells adjacent to the surrounding vein are destroyed. V.G. El., $170 \times$.

F i g u r e 3. Liver from a female fox given a single dose of $9 \mathrm{mg}$ DMNA/kg B.W., and sacrified 53 days after exposure. Around obliterated hepatic vessel (V) blood filled rooms (B) between irregular liver cell laminae represent the early stage of a hemangiomatous liver tumor. Ladewig Mallory, $170 \times$.

Fig u re 4. Liver from a male fox given $11 \mathrm{mg} D M N A / \mathrm{kg} \mathrm{B}$.W. and sacrificed after 380 days. Sublobular vein (V s) showing thickened wall with proliferation of the connective tissue and smooth muscle cell layers. Spaces containing blood and lymph are seen in the wall of the hypertropic vessel (n). Sinusoids are dilated into blood rooms (b) and lined with hypertrofic endothelium cells. The liver cell laminae markedly irregular, many multinucleated hepatocytes. In addition to the phleomorphic picture seen here, hemangiomatous tumors were found. Ladewig Mallory, $170 \times$.

Fig u re 5. Liver from a female fox given a single dose, $9 \mathrm{mg}$ DMNA/kg, B.W. and sacrificed 53 days after exposure. Note the nodular build-up of chondroid lamellae (C) and foci of hematopoietic tissue (h). Ladewig Mallory, $170 \times$.

F i g u re 6. Heart from fox given a single dose, $9 \mathrm{mg}$ DMNA/kg, B.W. and sacrificed 23 days after exposure. Arterial occulusive changes (A). V.G. El., $170 \times$. 
Figure 7. Liver from male fox exposed twice weekly with 3.5 $\mathrm{mg}$ DMNA/kg B.W. sacrificed after 112 days. Scar tissue in the centrolobular area ( $\mathrm{V} \mathrm{c}$ ) has closed the central vein and connective tissue is growing into the surrounding area. V.G. El., $170 \times$.

Figure 8. Liver from fox exposed twice weekly with $3.5 \mathrm{mg}$ DMNA/kg B.W. Sublobular vein (V s) almost occluded and some growth of connective tissue into the surrounding liver tissue. Ladewig Mallory, $170 \times$.

Fig u re 9. Liver from the same fox as in Fig. 8. Sublobular vein (V s) showing thickened wall with proliferation of the connective tissue and smooth muscle cell layers. Endothelium lined spaces inside the hypertropic vessel wall (n) and adjacent chondroid tissue (c). Liver cell laminae markedly irregular. V.G. El., $170 \times$.

Figure 10. Kidney from fox exposed twice weekly with $3.5 \mathrm{mg}$ DMNA/kg B.W. Moderate fibrosis of glomerular loops, acute degenerative changes in the epithelium of the proximal convolution of a nephron (d) V.G. El., $400 \times$. 


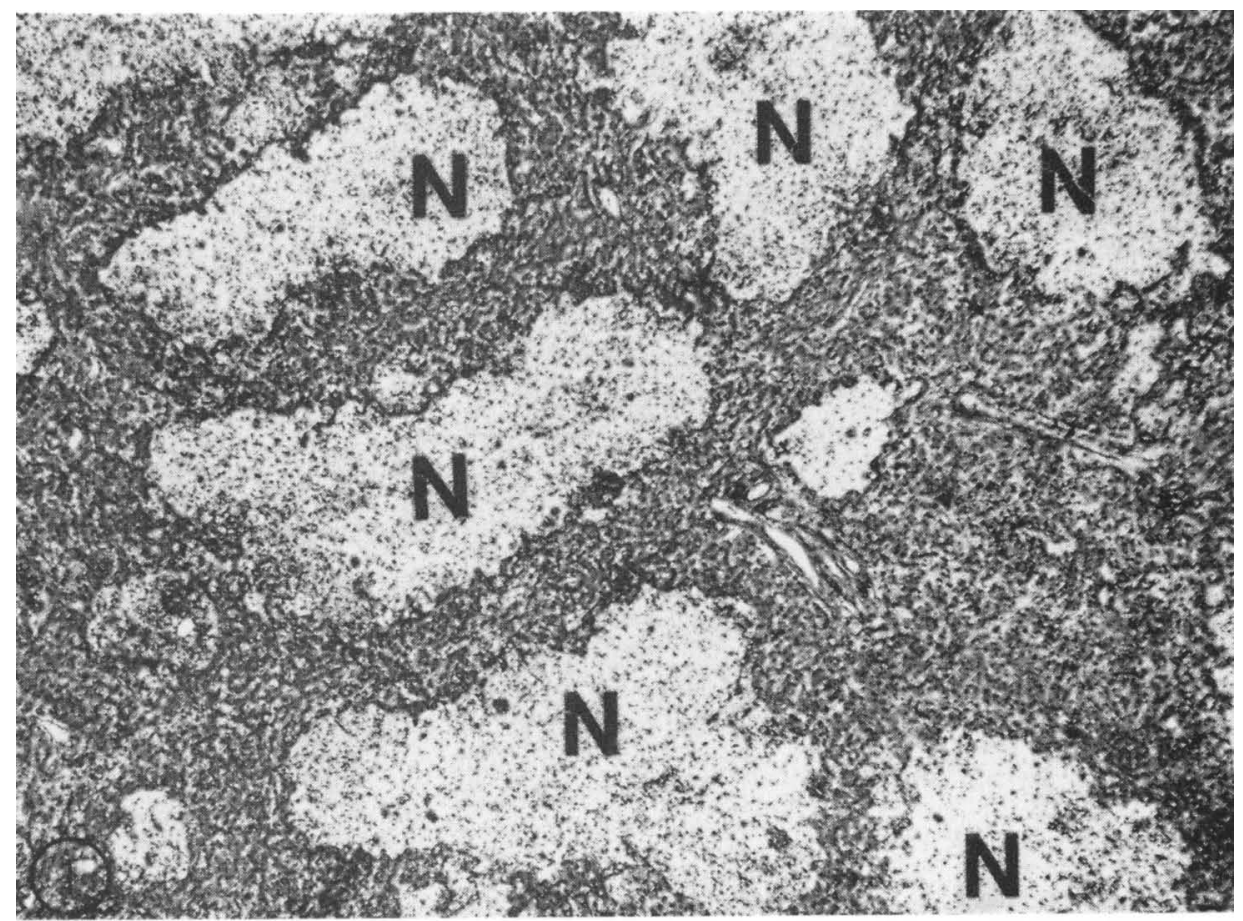

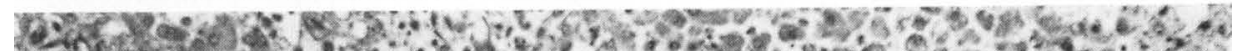

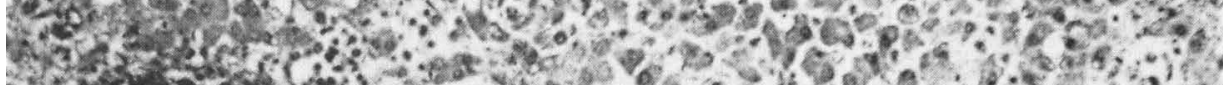

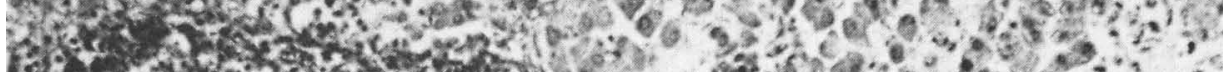

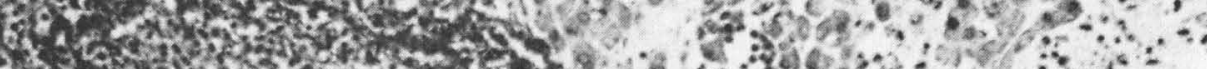

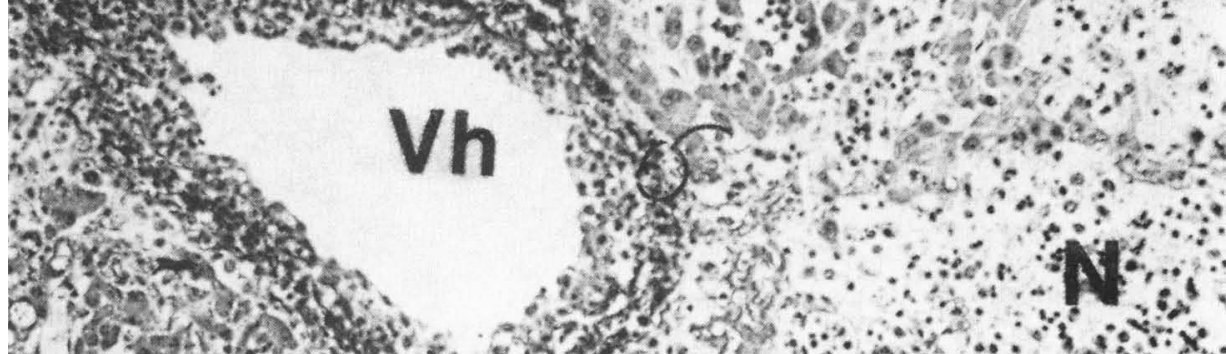

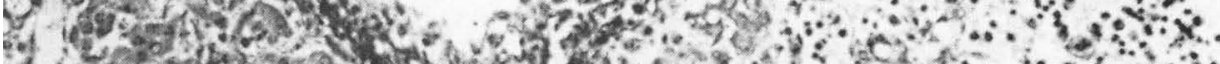

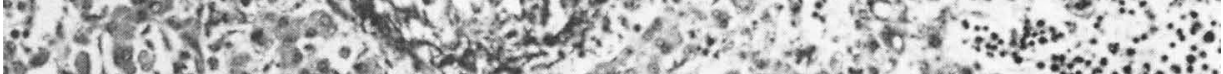

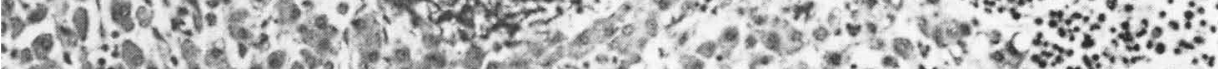

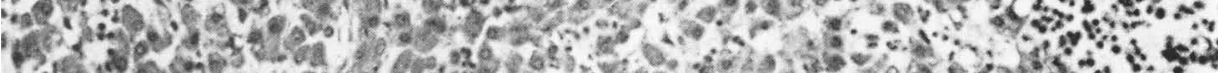

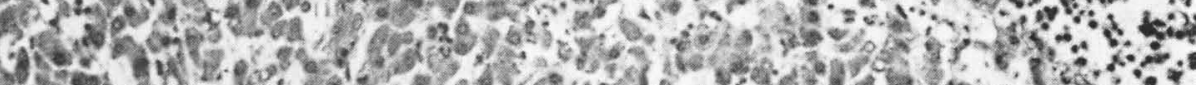

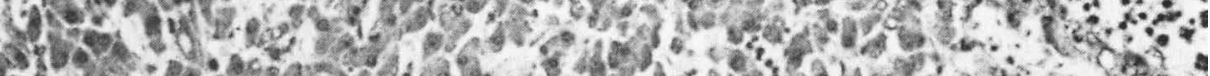

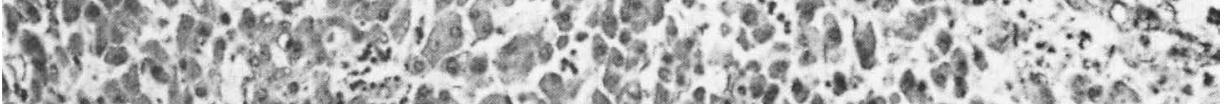

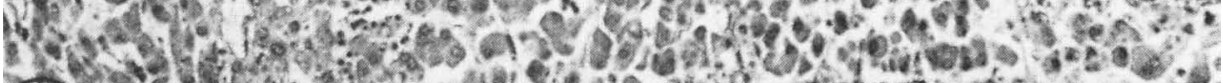

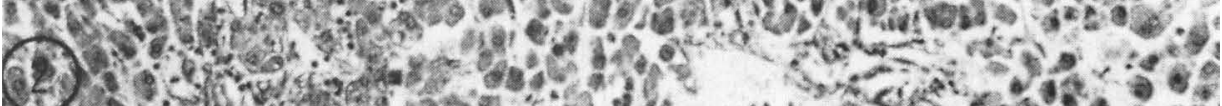




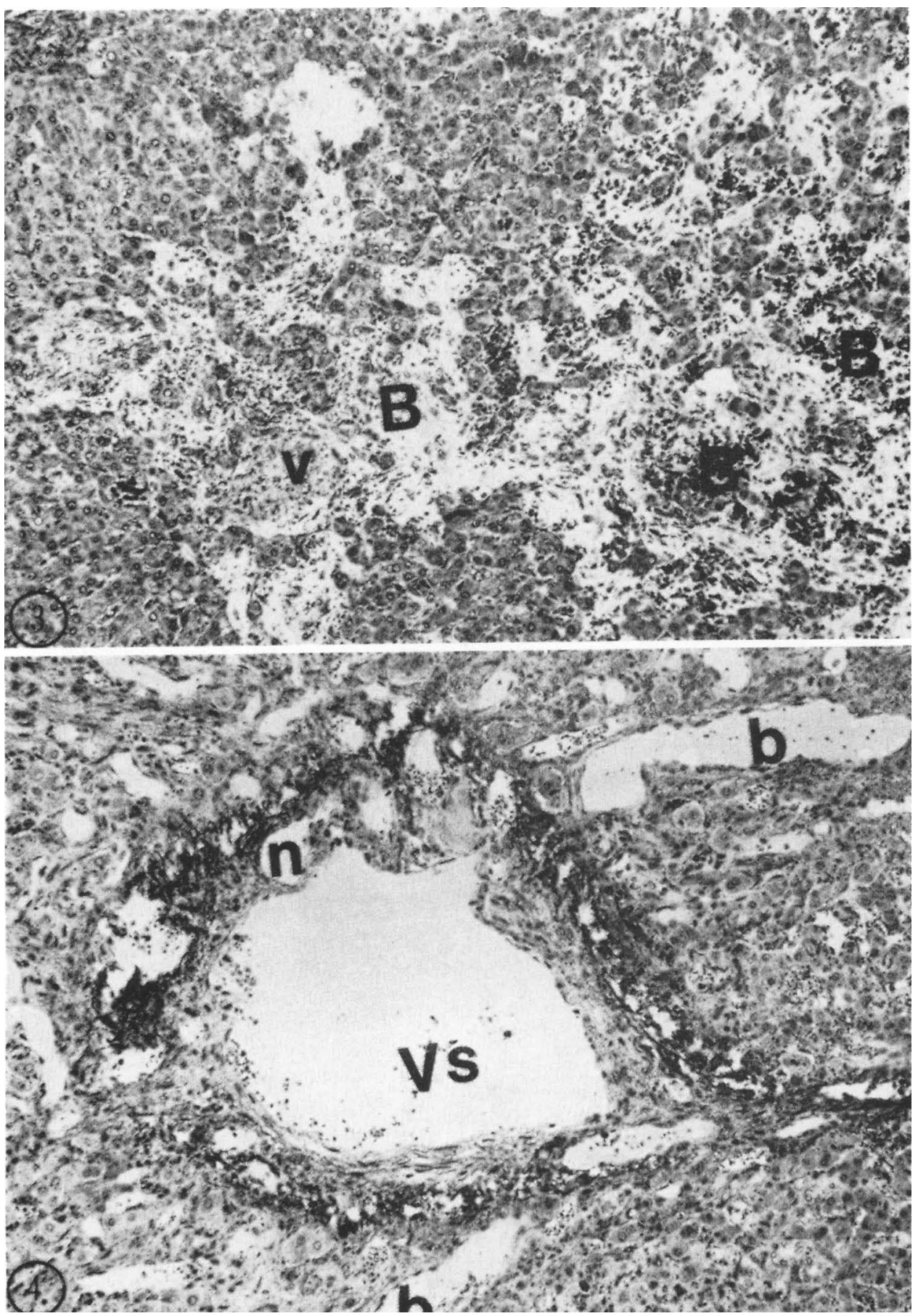




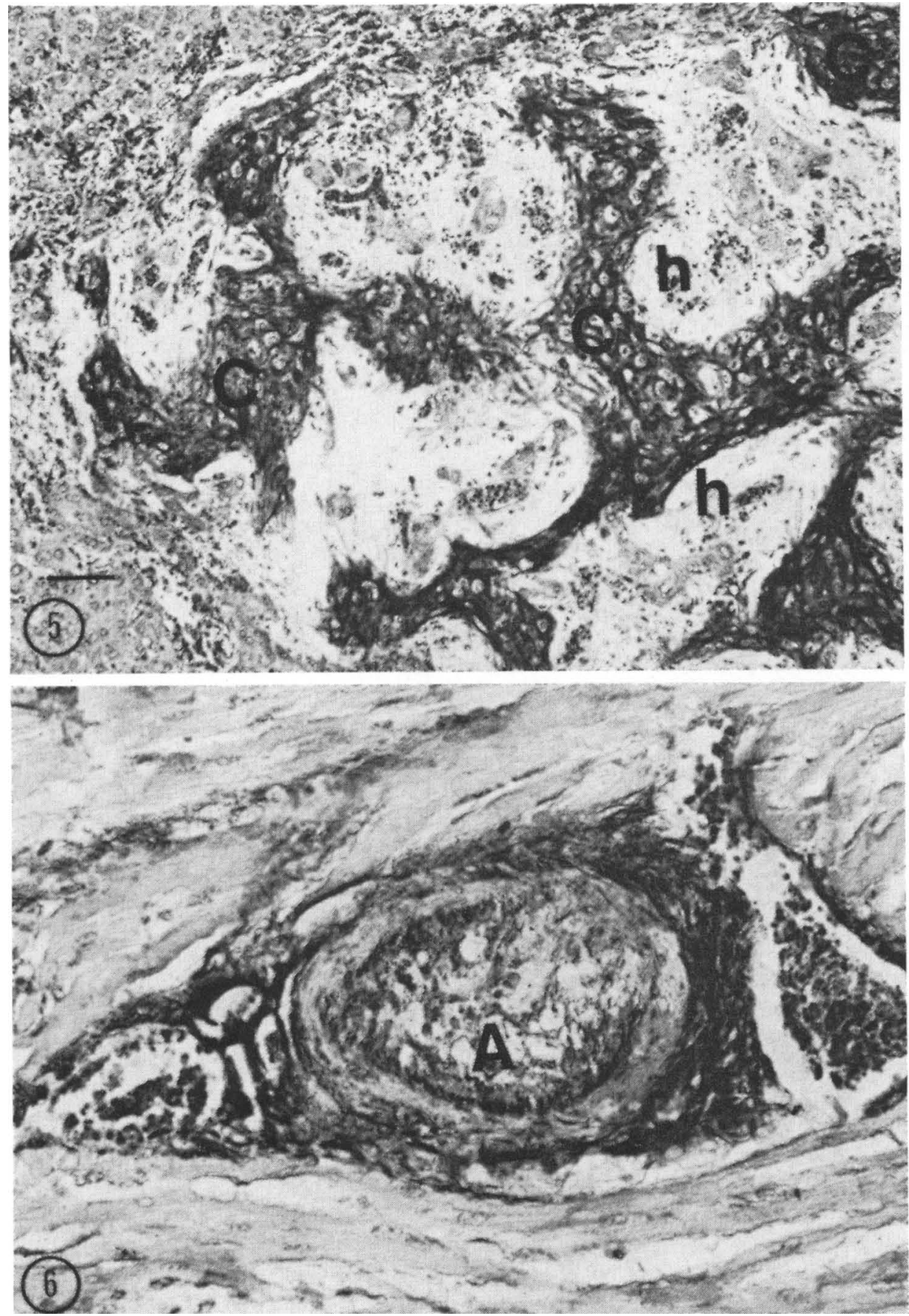




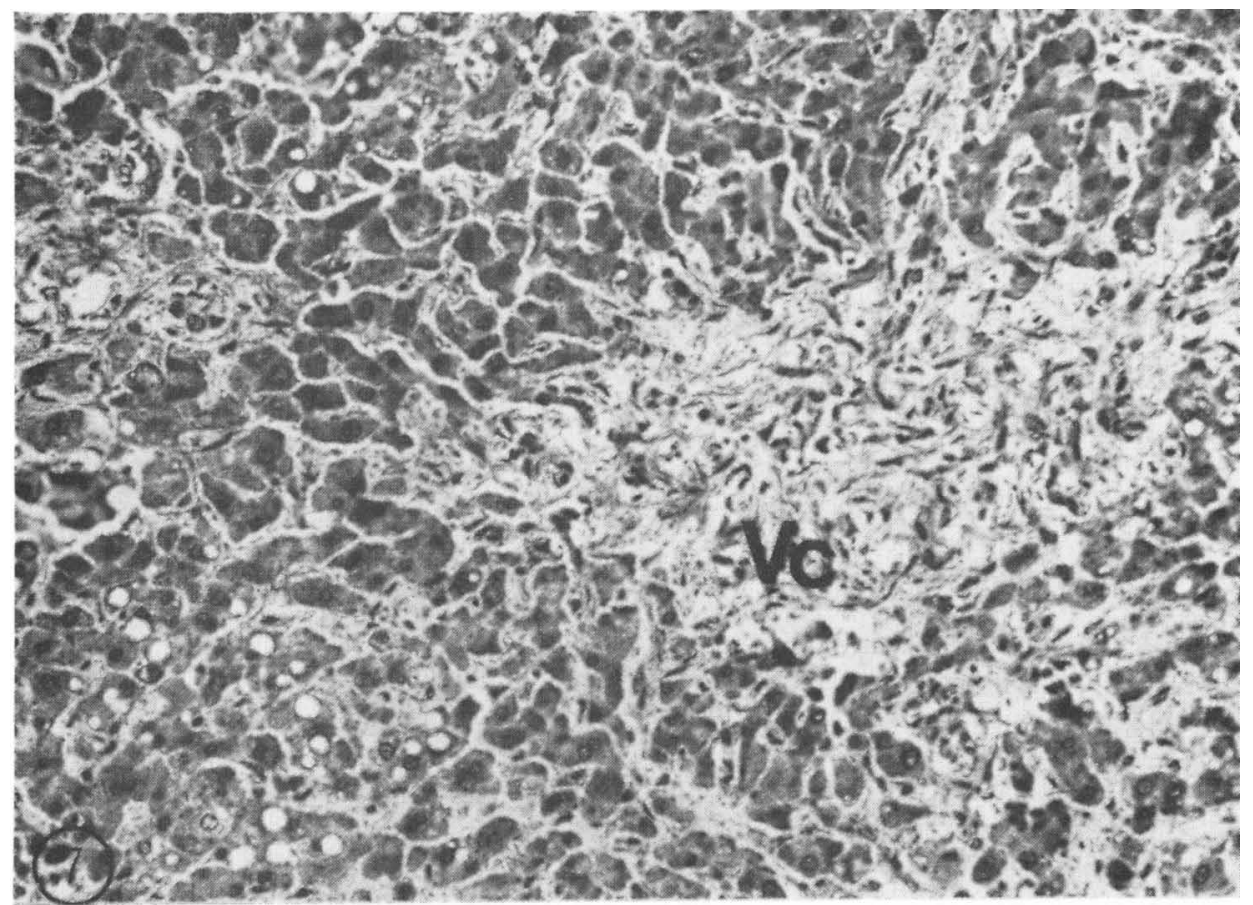

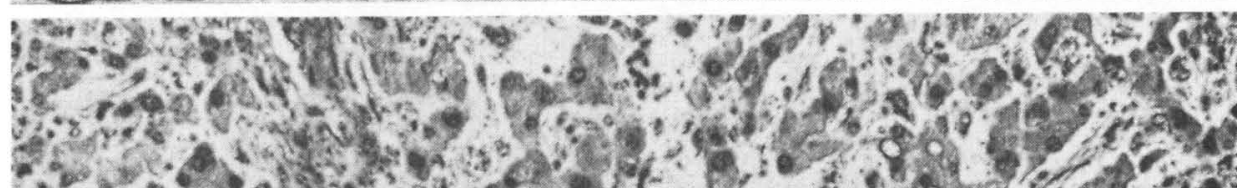

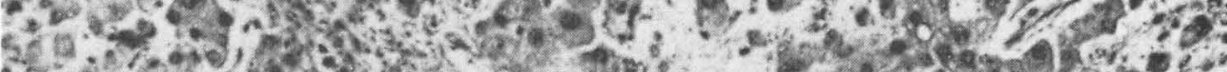

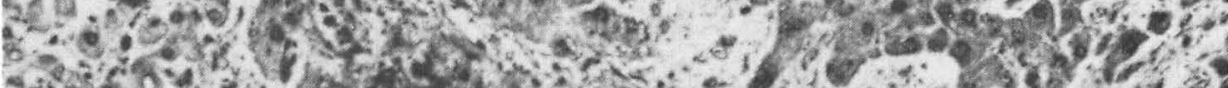

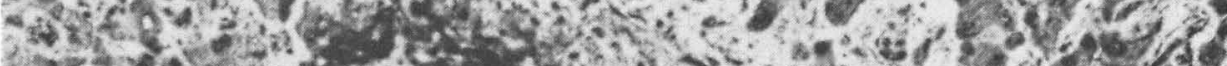

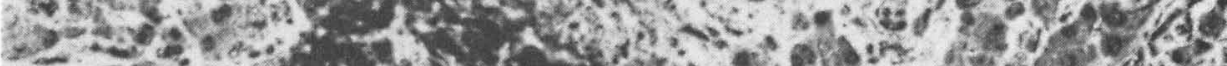

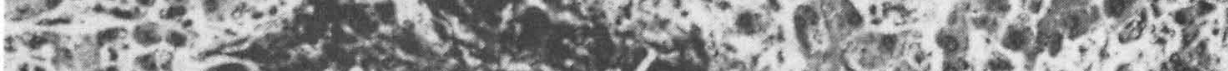

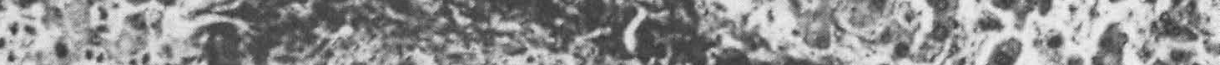

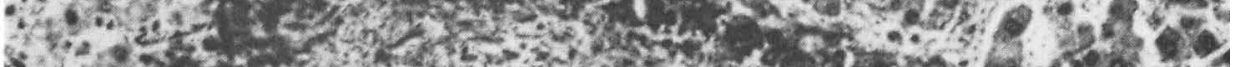

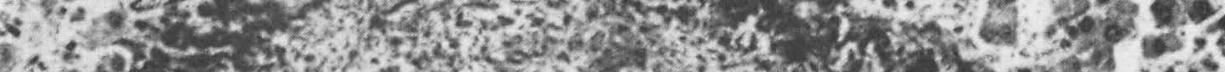

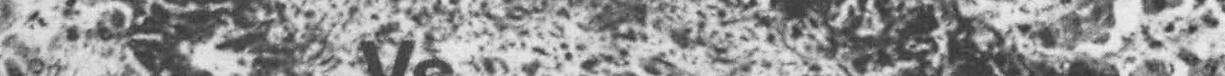

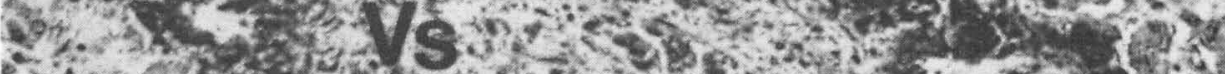

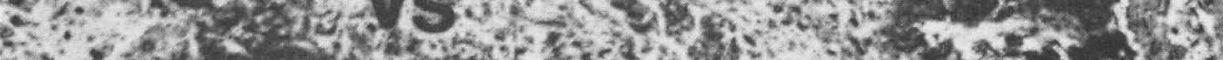

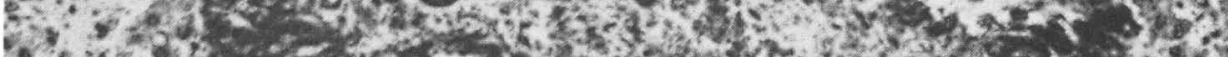

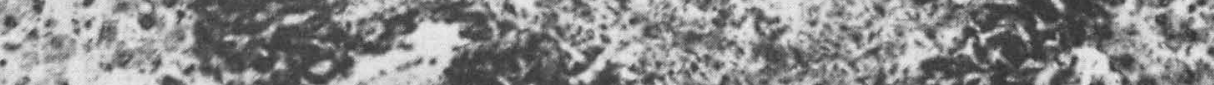

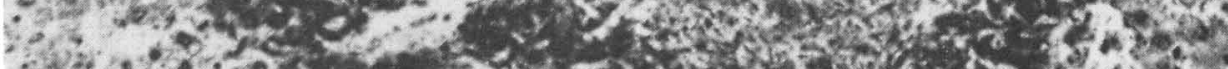
2.

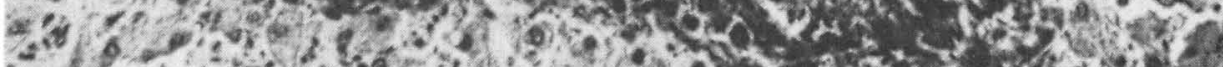

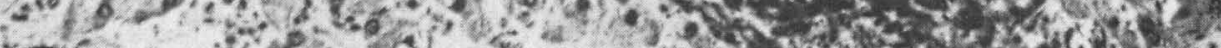

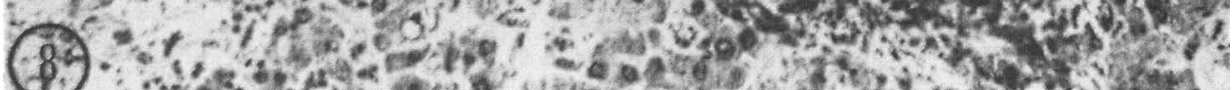




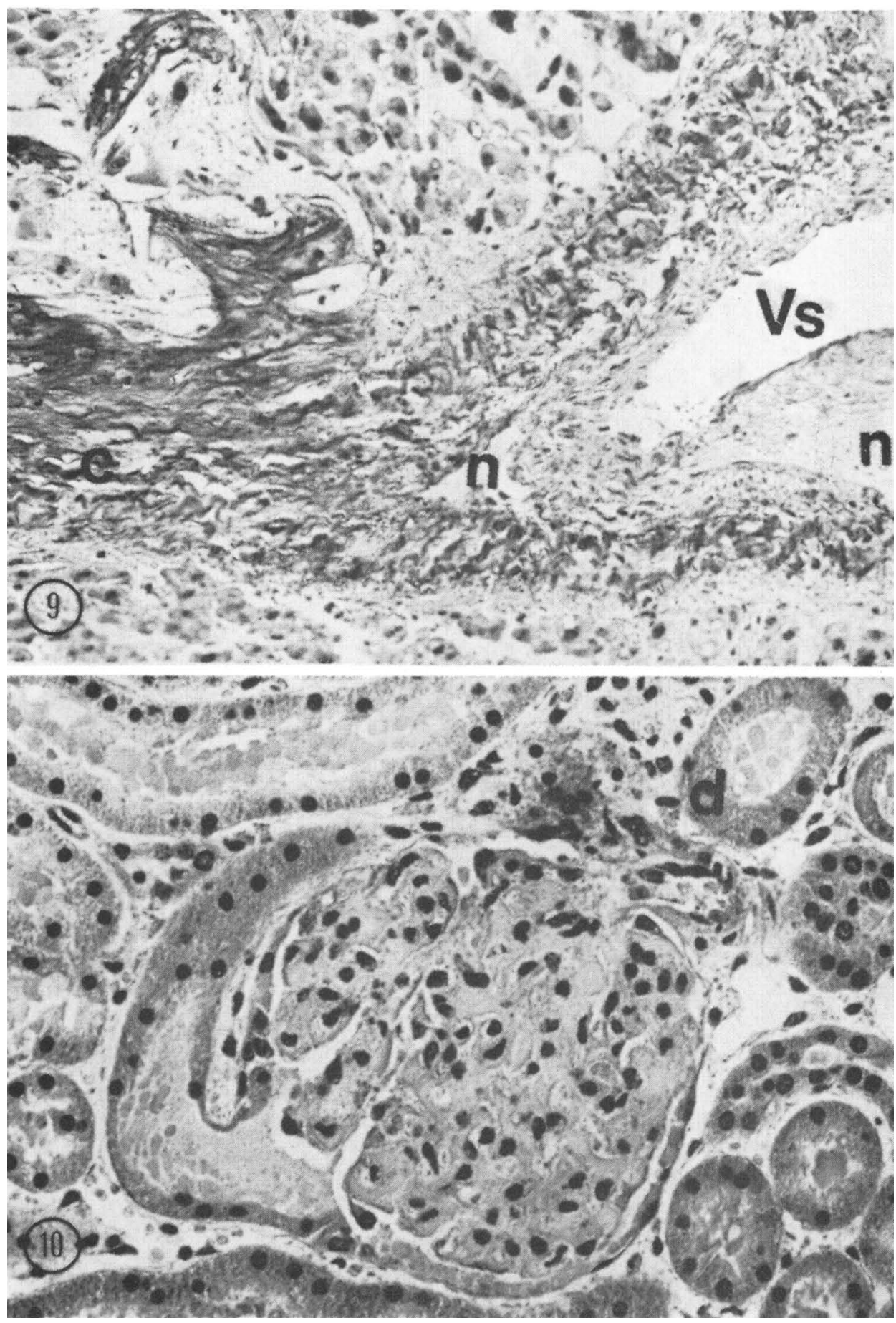


route of administration. Some animals lost their appetite, drank heavily and became lethargic in 2 to 3 days. Eleven foxes died within 4 days of exposure, however, 8 animals lived until 120 days. Eighteen other foxes were sacrificed between 13 and 380 days following exposure, but of those who were sacrificed at less than 4 weeks many were clinically ill with ascites at the time of sacrifice. Of the 7 animals who received $10 \mathrm{mg}$ DMNA $/ \mathrm{kg} \mathrm{B.W}$. subcutaneously, 3 died within 3 days, 1 lived to 4 months and 3 were sacrificed. Since roughly half of the animals died, we considered this as the $\mathrm{LD}_{50}$. In the groups receiving $14 \mathrm{mg}$ DMNA/kg B.W., 3 were given subcutaneous injections, 2 received the DMNA via a stomach tube and 1 ingested the DMNA in its food. Two from the subcutaneous group lived 3 and 10 days, but the third animal lived until 95 days when it was sacrificed. Two of the animals fed by stomach tube lived 3 days, or were sacrificed at 19 days. The animal fed DMNA in its food lived 7 days.

T a b l e 3. Experiment I. Blue foxes exposed to a single dose of dimethylnitrosamine (DMNA).

\begin{tabular}{|c|c|c|c|c|c|c|c|c|c|}
\hline \multirow{2}{*}{$\begin{array}{l}\text { Dose of } \\
\text { DMNA } \\
\text { (mg/kg } \\
\text { B.W.) }\end{array}$} & \multirow{2}{*}{$\begin{array}{c}\text { Num- } \\
\text { ber } \\
\text { of } \\
\text { foxes }\end{array}$} & \multicolumn{2}{|c|}{ Application } & \multicolumn{3}{|c|}{$\begin{array}{l}\text { Animals dying as a } \\
\text { result of disease }\end{array}$} & \multicolumn{3}{|c|}{ Animals sacrificed } \\
\hline & & teral & Sidat & number & $\overline{\mathbf{x}}_{(\mathrm{d}}$ & $\begin{array}{l}\text { range } \\
\text { ys) }\end{array}$ & number & $\overline{\mathbf{x}}$ & range \\
\hline 8.0 & 5 & 5 & - & 一 & 一 & - & $\mathbf{5}$ & 17 & $16-20$ \\
\hline 9.0 & 6 & 5 & 1 & 1 & 2 & - & 5 & 36 & $21-53$ \\
\hline 10.0 & 7 & 7 & 一 & 4 & 30 & $2-120$ & 3 & 49 & $13-120$ \\
\hline 11.0 & 4 & 3 & 1 & 3 & 16 & $3-36$ & 1 & 380 & \\
\hline 12.0 & 3 & 2 & 1 & 2 & 32 & $24-40$ & 1 & 111 & \\
\hline 13.0 & 3 & 1 & 2 & 3 & 3 & $2-4$ & 1 & 23 & \\
\hline 14.0 & 6 & 3 & 3 & 4 & 6 & $3-10$ & 2 & 57 & $19-95$ \\
\hline 15.0 & 3 & - & 3 & 3 & 6 & $1-16$ & 一 & & \\
\hline Totals: & 37 & 26 & 11 & 19 & & & 18 & & \\
\hline
\end{tabular}

b) Laboratory and pathological findings. Animals that lived for more than $48 \mathrm{~h}$ after exposure showed about a three-fold increase in SGOT and SGPT levels. Serum protein decreased from 6.8 to $5.6 \mathrm{~g} / 100 \mathrm{ml}$ with a slight increase in the globulin fraction ( 1.3 to $1.6 \mathrm{~g} / 100 \mathrm{ml}$ ), but a remarkable drop was observed in the albumin fraction ( 5.5 to $3.9 \mathrm{~g} / 100 \mathrm{ml}$ ). Elevations in NPN (25.3 to $31.5 \mathrm{mg} / 100 \mathrm{ml}$ ) and bilirubin $(0.17$ 
to $2.6 \mathrm{mg} / 100 \mathrm{ml}$ ) were slight. Generally, jaundice became clinically evident shortly before death. In the majority of cases, the necropsy findings resulting from a single high intake dose included jaundice, ascites, hemorrhagic diathesis, hematomae in the duodenal wall ( $3-5 \mathrm{~cm}$ in diameter), fatty changes of the myocardial fibers and some tubular epithelial degeneration in the proximal convolution of the kidney. In the liver, acute centrolobular hemorrhagic necrosis and acute vascular changes with endothelial necrosis and bleeding into vessel walls, especially in the hepatic vein system, were common features. Thrombosis in the portal and hepatic veins and in the vessels of the kidney and heart also occurred.

The time at which the animals died offered an opportunity to study the dynamics of liver regeneration. After $2-3$ days, necrotic liver cells in the centrolobular area disappeared and the remaining spaces were filled with blood (Fig. 1). Inflammatory response and fibroblastic proliferation also commenced at this time. Liver cell regeneration was to some degree dependent on the changes in the hepatic vessel (Fig. 2). Some branches of the hepatic veins were completely occluded in just one week due to necrotic changes and inflammatory reactions in the vessel wall. This was accompanied by fibroblastic proliferation. The hepatic veno-occlusive disease seemed to progress many months after a single DMNA exposure. For example, at 53 days, $9 \mathrm{mg}$ of DMNA produced early hemangiomatous lesions (Fig. 3), at 4 months, $10 \mathrm{mg}$ produced scar fibrosis in the liver and at $12 \frac{1}{2}$ months, $11 \mathrm{mg}$ produced not only scar fibrosis, but multiple hemangiomatous tumors (Fig. 4). A common feature in the liver were small nodules composed of chondroid tissue mixed with small foci of hematopoietic cells (Fig. 5). These hematopoietic nodules were sometimes connected with the vessel wall.

Vessel changes were far more pronounced in hepatic veins, but such changes also occurred in other organs. In the heart, changes in arteries of intermediate diameter were often seen (Fig. 6). These changes consisted of hypertrophy and degeneration of the muscularis and elastica, resulting in a constriction of the lumen. As a result, there were partial occlusions in many vessels. Some congestion of renal glomeruli could be seen in the kidney of foxes who died after early exposure to DMNA. In animals living longer, these changes lead to a slight glomerular fibrosis. 
Experiment II. Foxes exposed to bi-weekly doses of DMNA

a) Ci inical course

Group 1. High doses of DMNA (3.5 m g/k g B.W.). Within a month, the foxes began to eat poorly so the actual intake of DMNA could not be accurately determined. The estimated intakes are shown in Table 4 and range from 45 to 60 $\mathrm{mg} / \mathrm{kg} \mathrm{B.W}$. The clinical signs which developed were much the same as seen in the foxes following a single dose. After 4 weeks, foxes in Group 1 lost weight, were apathetic, developed ascites, became jaundiced and shortly before death the feces was dark and mucoid in appearance. One fox died at 53 days and the remaining 6 were sacrificed from 48 to 112 experimental days because of chronic illness.

T a b l e 4. Experiment II. Effect of long-term exposure to dimethylnitrosamine (DMNA) in the blue foxes.

\begin{tabular}{|c|c|c|c|c|c|c|c|c|}
\hline \multirow[t]{2}{*}{ Group } & \multirow{2}{*}{$\begin{array}{l}\text { Num- } \\
\text { ber } \\
\text { of } \\
\text { ani- } \\
\text { mals }\end{array}$} & \multirow{2}{*}{$\begin{array}{c}\text { Bi- } \\
\text { weekly } \\
\text { dose }\end{array}$} & \multirow{2}{*}{$\begin{array}{c}\text { Esti- } \\
\text { mated } \\
\text { daily } \\
\text { expo- } \\
\text { sure }^{\star}\end{array}$} & \multicolumn{2}{|c|}{$\begin{array}{l}\text { Total of } \\
\text { DMNA } \\
\text { (mg/kg B.W.) }\end{array}$} & \multicolumn{2}{|c|}{$\begin{array}{l}\text { Days of } \\
\text { experiment }\end{array}$} & \multirow[t]{2}{*}{ Pathologic changes ${ }^{\star \star}$} \\
\hline & & & & $\overline{\mathbf{x}}$ & range & $\overline{\mathbf{x}}$ & range & \\
\hline 1 & 7 & 3.5 & 1.0 & 52 & $45-60$ & 76 & $48-112$ & $\begin{array}{l}\text { Icterus }(4) \text {; ascites (7); productive } \\
\text { vessel changes in liver (7); hemorrhagic } \\
\text { centrolobular liver necrosis }(1) ; \text { scar } \\
\text { fibrosis in liver }(6)\end{array}$ \\
\hline 2 & 5 & 0.7 & 0.2 & 65 & $46-70$ & 551 & $362-1155$ & $\begin{array}{l}\text { Icterus }(4) \text {; ascites (4); productive } \\
\text { vessel changes (5); liver cirrhosis (4); } \\
\text { coronary and renal infarct }(1) ; \text { heman- } \\
\text { giomatous liver tumors }(2)\end{array}$ \\
\hline 3 & 6 & 0.35 & 0.1 & 112 & $22-162$ & 1155 & $215-1627$ & $\begin{array}{l}\text { Hemocoeli (3); hemangiomatous liver } \\
\text { tumors (3); chromophobic pituitary } \\
\text { adenoma and hemorrhagic brain stem (1) }\end{array}$ \\
\hline
\end{tabular}

* See text for calculation.

** Number of animals in parenthesis.

Group 2. Intermediate dose of DMNA $(0.7 \mathrm{mg} /$ $\mathrm{kg}$ B.W.). Foxes in this group ate well for the first 10-11 months, but then refused some of their daily ration. The DMNA was removed from the diet after 360 days when 4 of the animals had ingested a total of approximately $70 \mathrm{mg}$. One female was mated and shortly thereafter the DMNA was removed from her diet and so she ingested only $46 \mathrm{mg}$. After the DMNA intake was terminated, the 4 foxes who received a total of $70 \mathrm{mg}$ of DMNA died during the next $2-60$ days. In the last month of their life they experienced episodes of unconsciousness and developed 
jaundice and ascites. Only the once pregnant female with the lower intake behaved normally. She was sacrificed 3 years and 2 months after the experiment began.

Group 3. Low dose of DMNA $(0.35 \mathrm{mg} / \mathrm{kg}$ B.W. $)$. One of the 6 foxes became atactic, lost vision and died 215 days after the beginning of the experiment. The remaining 5 ate well, behaved normally and after 16 months of exposure were still clinically normal. One of these 5 animals, who was completely healthy, was sacrificed at 490 days. There were essentially no pathological changes in this animal. A liver biopsy was taken of each of the 4 remaining foxes 3 to 4 years later. Two of these 4 animals were females and they both conceived normal-sized litters. After weaning, these animals were returned to the DMNA regimen and then at 1398 and 1627 days from the beginning of the experiment they suddenly died without showing signs of illness. One other fox was sacrificed after 1581 days showing seizures and ascites. The last animal in this group behaved normally until 1619 days and then was sacrificed.

Control group. The animals were all healthy and behaved normally.

b) Laboratory and pathological changes

Groups 1 and 2. Bi-weekly doses of DMNA (3.5 $\mathrm{mg}$ a n d $0.7 \mathrm{mg} / \mathrm{kg}$ B.W.). Enzyme and other biochemical parameters became more abnormal as exposure time was increased, except that serum albumin levels decreased (Table 5). No changes were observed in bilirubin levels during the next 2-60 days in the foxes in Group 2.

The foxes who died or were sacrificed because of illness were icteric, emaciated, showed subcutaneous edema, hemorrhages into the mucous merbranes and fluid in serosal cavities. The hearts were enlarged, flabby, and yellowish-brown by gross examination. Lungs were congested, as were the portal and abdominal veins. The livers in the more acute cases were somewhat enlarged, the color was a bluish-red and the surface was granular. In the more protracted cases, all lobes of the liver were smaller than normal, had nodular surfaces and fibrotic thickening of the liver capsule. The liver parenchyma was partly fibrotic and the color varied from yellowish-gray to red-blue. The spleen were moderately enlarged and the kidneys were 
T a ble 5. Experiment II. Biochemical analyses of serum from controls and foxes treated with DMNA (Group 2).

\begin{tabular}{lcrrccccc}
\hline $\begin{array}{l}\text { Time of } \\
\text { Exposure }\end{array}$ & $\begin{array}{c}\text { Experi- } \\
\text { mental } \\
\text { animal } \\
\text { No. }\end{array}$ & $\begin{array}{c}\text { SGOT } \\
\text { mU/ml }\end{array}$ & $\begin{array}{c}\text { SGPT } \\
\text { mU/ml }\end{array}$ & $\begin{array}{c}\text { Total protein } \\
\text { g/100 ml }\end{array}$ & $\begin{array}{c}\text { Albumin } \\
\text { g/100 ml }\end{array}$ & $\begin{array}{c}\text { Globulin } \\
\text { g/100 ml }\end{array}$ & $\begin{array}{c}\text { Bilirubin } \\
\text { mg/100 ml }\end{array}$ & $\begin{array}{c}\text { NPN } \\
\text { mg/100 } \mathbf{~ m l ~}\end{array}$ \\
\hline Controls & - & $20 \pm 5$ & $41 \pm 15$ & $6.80 \pm 0.40$ & $5.50 \pm 0.30$ & $1.30 \pm 0.30$ & $0.17 \pm 0.03$ & $25.3 \pm 5.2$ \\
5 months & 1 & 110 & 324 & 6.85 & 5.37 & 1.48 & 0.2 & 21 \\
& 2 & 23 & 78 & 6.76 & 5.65 & 1.11 & 0.2 & 18 \\
& 3 & 39 & 84 & 6.76 & 5.40 & 1.36 & 0.2 & 20 \\
& 4 & 282 & 342 & 6.40 & 5.11 & 1.29 & -17 & 24 \\
& 5 & 35 & 70 & 6.10 & 5.25 & 0.85 & 0.17 & 24 \\
& 1 & 168 & 490 & 7.13 & 4.65 & 2.48 & 0.2 & 19.1 \\
& 2 & 92 & 297 & 7.15 & 5.38 & 1.77 & 0.2 & 21.6 \\
& 3 & 82 & 184 & 7.31 & 4.70 & 2.61 & 0.2 & 20.1 \\
& 4 & 249 & 589 & 6.72 & 4.76 & 1.96 & 0.3 & 22.0 \\
& 5 & 109 & 231 & 6.40 & 4.50 & 1.80 & 0.1 & 18.6 \\
\hline
\end{tabular}

normal in size and shape. In some cases small infarcts were found in the liver, spleen, kidney and the heart. Gastric and intestinal contents were unremarkable except for slight bleeding into the lower colon and rectum.

The histological changes were generally similar to those described in Experiment I. The liver showed a progressive obliteration of the hepatic venous system, most pronounced in the central and sublobular veins (Figs. 7 and 8). Liver cells were pleomorphic and there was diffuse liver fibriosis around the central veins. Small nodules of chondroid tissue were present in the adventitia of some sublobular veins. This apparently arose by a gradual change of connective tissue into cartilagenous tissue containing islands of hemopoietic tissue (Fig. 9). There were also small areas of hemangiomatous tumors in the livers of some foxes in Group 2. These represented early changes and were most pronounced in the female used for breeding which received the $46 \mathrm{mg}$ DMNA dose. She was first sacrificed at 3 years and 2 months after the first exposure without showing any symptoms of disease. Neoplasia usually occurred in connection with thickened hepatic vessel walls. Kidney lesions consisted mainly of changes in glomerular loops, sometimes leading to moderate fibrosis (Fig. 10). Moderate vascular changes were seen in other organs as well, particularly in the myocardium (as in Fig. 6). 
Group 3. Bi-weekly doses of DMNA $(0.35 \mathrm{mg} /$ $\mathrm{kg}$ B.W.). The liver of the fox which expired after 215 days was normal and only minimal thickening of the wall of a few hepatic veins was noted. Histological examination revealed a small brain tumor in the hypothalamus which was diagnosed as a pituitary adenoma. Thrombotic vessel changes and hemorrhages in the brain stem were the ultimate cause of the death. A fox sacrificed after 490 days, showed no gross changes and only minor occlusive changes of some branches of the hepatic veins. The liver biopsies taken from the remaining foxes after 3 to 4 years of experimental feeding, were essentially normal and showed only minimal thickening of the wall of some of the branches of the hepatic veins.

The 2 mated females expired suddenly and showed similar pathological changes, i.e. there were multiple bluish-red tumors in the liver lobules which measured $2-50 \mathrm{~mm}$ in diameter and 1 tumor situated close to the capsule had ruptured causing bleeding and death. Smaller metastases were found in the lymph noduli in the omentum, and on the peritoneum. The histological picture of these tumors appeared to be that of a hemangiosarcoma. Tumors were often closely connected to hepatic vessels which were more or less occluded. In the wall of the thickened sublobular veins, hemangiosarcomatous tissue could be seen. In some liver tumors, metaplastic growth of parenchyma and biliary duct cells were mixed within the hemangiosarcomatous tissue. One male fox, sacrificed because of convulsions showed ascites and slight liver capsular fibrosis but was without other gross anatomical changes. Some thickening in the wall of the hepatic veins was seen by histological examination. There were also areas with acute centrolobular necrosis and hemorrhage, as well as insulae of malignant liver cells which had metastasized to the cerebral vessels.

The last fox sacrificed after 1619 experimental days did not show any gross pathological changes. Histological examination revealed minimal thickening in some branches of the hepatic veins and this was associated with pre-cancerous changes of the same type as seen in Fig. 3. 
Experiment III. Fish meal with or without DMNA

a) Clinica l course. The foxes in this experiment ate well and increased normally in weight. They were all healthy, were sacrificed after 120 days of experimental feeding and pelted for commercial use. The uptake of DMNA from the food in 2 of the 5 groups are presented in Table 6. From the increase in body weight and the amount of food consumed, the actual content of DMNA/kg of weight could be calculated.

b) Pathological changes. All the foxes were well nourished and did not show any organ changes. Histological examination revealed normal liver cells and architecture in all animals. Hepatic veins were normal in essentially all of the animals. In 5 foxes from Group 2 (Table 6) some hepatic vessels may have been slightly thickened.

The control groups did not show any liver changes.

T a b l e 6. Experiment III. Consumption of DMNA (mg/kg B.W.) per day in 2 groups of foxes during different growth periods.

\begin{tabular}{ccc}
\hline $\begin{array}{c}\text { Experimental } \\
\text { period } \\
\text { (days) }\end{array}$ & \multicolumn{2}{c}{ Daily DMNA intake (mg/kg B.W.) } \\
\cline { 2 - 3 } & Group 1 & Group 2 \\
\hline 8 & 0.04 & 0.13 \\
14 & 0.03 & 0.11 \\
14 & 0.03 & 0.09 \\
21 & 0.03 & 0.08 \\
21 & 0.03 & 0.08 \\
21 & 0.02 & 0.07 \\
21 & 0.02 & 0.06 \\
\hline
\end{tabular}

\section{DISCUSSION}

The single dose required to produce the $\mathrm{LD}_{50}$ for blue foxes in our experiments was $10 \mathrm{mg}$ of DMNA/ $\mathrm{kg} \mathrm{B.W}$. The mode of application appears to be unimportant with regard to toxicity, but DMNA was more accurately measured from a parenteral application than from oral exposure, because animals often waste their feed. In the case of administration via a stomach tube, vomiting may occur. Some of the foxes which were sacrificed in Experiment I would have eventually died from their liver disease, as a result of progressive vascular changes. When these changes are rapid, one sees scar fibrosis and liver failure, but 
if the changes progress more slowly, tumors develop. The $\mathbf{L D}_{50}$ for laboratory animals is usually based upon a very short observation period of 3-6 days, which is far too short for DMNA evaluation. Some of the animals in our $10 \mathrm{mg} / \mathrm{kg} \mathrm{B.W.} \mathrm{group,}$ lived up to 120 days because DMNA produces a progressive damage to the hepatic vessels. The rate at which hepatic vascular lesions occur appears to be dose-dependent. The cumulative effect of bi-weekly doses of $3.5 \mathrm{mg}$ of DMNA/ $\mathrm{kg} \mathrm{B.W}$. in Group 1 resulted in loss of appetite and partial refusal of food. Because of this, the actual total amount of DMNA consumed was difficult to access. We estimated the approximate intake to be $45 \mathrm{mg}$ DMNA $/ \mathrm{kg} \mathrm{B.W.} \mathrm{after} 52$ days of feeding and $60 \mathrm{mg}$ DMNA $/ \mathrm{kg}$ B.W. after 112 days. All of these animals showed thickening and/or some occlusive changes in the branches of hepatic veins, which lead to centrolobular fibrosis. Vessel changes outside the liver, were most pronounced in the renal glomeruli which resulted in slight fibrosis of some glomerular loops. Similar changes were seen in Group 2, but due to the lower dose, a longer interval of time was required to reach the same cumulative DMNA level. Progressive liver lesions, as evidenced by SGOT and SGPT levels, eventually lead to liver failure or the formation of hemangiomatous tumors which often ruptured, caused bleeding and sudden death. The multiple infarcts observed in the kidney, liver, spleen and heart of individual animals underline the common toxic effect of DMNA to the vessels. Undoubtedly, these changes are most pronounced in branches of the hepatic veins, although some pathology can be observed in the vessels of other viscera. This explains the occurrence of hematomas in many of the foxes exposed to a single dose. The first fox that died in Group 3 had a small brain tumor, but the eventual cause of death was intracerebral bleeding caused by vascular changes and trombosis.

With the higher doses administered either singularly or biweekly, vessel changes were combined with hepatic necrosis. The acute necrosis of the endothelial cells in vessel walls can be easily overlooked. The occlusive changes in hepatic vessels have been explained as a side-effect due the liver cell necrosis (McLean et al. 1965), but we maintain that these changes are caused by the DMNA. Smaller doses of DMNA did not produce centrolobular hemorrhagic necrosis, but as DMNA and its metabolites accumulate, changes of the occlusive type were seen. Hemangiomatous 
tumors seemed to arise from this type of altered vessel. Tumors of this kind are pleomorphic and undoubtedly some are hemangio-sarcomas. Other hepatic tumors have epithelial components consisting of hepatic and bile duct cells. Metastasis occurred in the mesenteric lymph nodes, but could also be found in the brain. The cerebral metastasis in 1 fox in Experiment II. Group 3 was a hepatocarcinoma, but the primary liver tumor was so small that it was macroscopically undetected. Hematopoetic nodules in the liver were very common and were found even after a single exposure. The acute centrolobular hemorrhagic necrosis seen after a single dose of DMNA can be repaired. Regeneration of destroyed liver cells usually take place within $3-4$ weeks.

The degree of acute changes in the vessel due to DMNA are important for the course of the disease. Our previous experiments in swine, sheep, cows, mink and foxes suggested that the toxic injury to hepatic veins may have been the underlying factor in the development of cirrhosis (Koppang 1974, 1980). In cattle, sheep and mink, daily doses below $0.15 \mathrm{mg}$ of DMNA/ $\mathrm{kg}$ B.W. will usually not cause liver failure and this is an agreement with the present report.

Animals who were fed fish meal containing DMNA (Experiment III, Tables 2 and 6) never received levels above $0.13 \mathrm{mg}$ DMNA/kg B.W./day and the exposure time was only 120 days. This is below the amount of DMNA that produces pathological changes in the fox. If the experiment had proceeded over 4-5 years, the animals might have developed tumors as in Group 3 of Experiment II. This observation is in agreement with our mink experiments using a similar feed. With longer exposure time, the mink developed liver tumors (Koppang \& Rimeslatten 1976). If, therefore, the foxes had been exposed longer in Experiment III, they undoubtedly would have developed tumors as did the foxes in Experiment II, Group 3.

The acute changes in humans caused of DMNA vapor (Freund 1937 ) is the same as seen in animals by oral application. Barnes $\&$ Magee (1954) reported the development of liver cirrhosis after an acute exposure in humans, which we in our experiment have also seen in foxes. 


\section{ACKNOWLEDGEMENTS}

The authors wish to express gratitude to the Department of Biochemistry, Veterinary College of Norway for analyzing the blood samples, and to the Herring Oil and Herring Meal Industry's Research Institute for preparing the experimental meals and performing the DMNA analyses.

\section{REFERENCES}

Aldal, A. Personal communication 1964.

Barnes, J. M. \& P. N. Magee: Some toxic properties of dimethylnitrosamine. Brit. J. industr. Med. 1954, 11, 167-174.

Druckrey, H., R. Preussmann, S. Ivankovic \& D. Schmähl: Organotrope carcinogene Wirkungen bei 65 verschiedenen $\mathrm{N}$-NitrosoVerbindungen an BD-Ratten. (Organotrophic carcinogenic effects of 65 different N-Nitrosocompounds in BD-rats). Z. Krebsforsch. 1967, 69, 103-201.

Ender, F., G. Havre, A. Helgebostad, N. Koppang, R. Madsen \& L. Ceh: Isolation and identification of a hepatotoxic factor in herring meal produced from sodium nitrite preserved herring. Naturwissenschaften $1964,51,637-638$.

Freund, $H$. A.: Clinical manifestations and studies in parenchymatous hepatitis. Ann. intern. Med. 1937, 10, 1144-1155.

Jacobson, K. H., H. J. Wheelwright jr., J. H. Clem \& R. N. Shannon: Studies on the toxicology of $\mathrm{N}$-Nitrosodimethylamine vapor. Arch. industr. Hith 1955, 12, 617-622.

Koppang, N.: Proceed. 9. Nordic Vet. Congr., Copenhagen 1962, pp. 777-778.

Koppang, N.: An outbreak of toxic liver injury in ruminants. Nord. Vet.-Med. 1964, 16, 305-322.

Koppang, N.: A severe progressive liver disease in fur animals. I. Symptoms and organ changes. Nord. Vet.-Med. 1966, 18, 205209.

Koppang, N.: Dimethylnitrosamine - formation in fish meal and toxic effects in pigs. Amer. J. Path. 1974 a, 74, 95-106.

Koppang, N.: Toxic effect of dimethylnitrosamine in cows. J. nat. Cancer Inst. 1974 b, 52, 523-531.

Koppang, N.: The toxic effects of dimethylnitrosamine in sheep. Acta vet. scand. $1974 \mathrm{c}, 15,533-543$.

Koppang, N.: A survey of feeding N-Nitrosodimethylamine (NDMA) to domestic animals over an 18 year period. In: E. A. Walker, L. Griciute, M. Castegnaro \& M. Börzsönyi (eds.). N-Nitroso Compounds: Analysis, Formation and Occurrence. IARC Scient. Publ. No. 31. Lyon 1980, pp. 779-785.

Koppang, N.\& A. Helgebostad: Ondartet leversyke hos pelsdyr. (Malignant liver disease in fur animals). Norsk Pelsdyrblad 1962, $36,317-318$. 
Koppang, N.\& A. Helgebostad: Toxic hepatosis in fur animals. II. The etiology eluciated by feeding experiments. III. Conditions affecting the formation of the toxic factor in herring meal. Nord. Vet.-Med. 1966, 18, 210-225.

Koppang, N.\&H. Rimeslåtten: Toxic and carcinogenic effects of nitrosodimethylamine in mink. In: E. A. Walker, P. Bogovski \& L. Griciute (eds.) Environmental N-Nitroso Compounds Analysis and Formation. IARC Scient. Publ. No. 14, Lyon 1976, pp. $443-452$.

Lydersen, D. L. \& K. Nagy: Polarographic determination of dimethylnitrosamine in fish products. Z. anal. Chem. 1967, 230, 277282.

Magee, P. N. \& J. M. Barnes: The production of malignant primary hepatic tumours in the rat by feeding dimethylnitrosamine. Brit. J. Cancer 1956, 10, 114-122.

Ibid.: Carcinogenic nitroso compounds. Adv. Cancer Res. 1967, 10, 163-246.

McLean, E., G. Bras \& A. E. McLean: Venous occlusions in the liver following dimethylnitrosamine. Brit. J. exp. Path. 1965, 46, $367-369$.

O'Leary, J. F., A. H. Oikemus, B. Harrison \& A. Brandsford: Some toxic effects of dimethylnitrosamine. Fed. Proc. 1955, 14, 375375.

Sakshaug, J., E. Søgnen, M. A. Hansen \& N. Koppang: Dimethylnitrosamine, its hepatotoxic effect in sheep and its occurrence in toxic batches of herring meal. Nature (Lond.) 1965, 206, 1261-1262.

\section{SAMMENDRAG}

Toksisk og carcinogen virkning av dimethylnitrosamin pd rev.

Enkeltdoser av DMNA i størrelsesorden $8-15 \mathrm{mg} / \mathrm{kg}$ l.v. ble gitt enten $i$ fóret, med svelgsonde eller ved subcutan applikasjon til 37 rever. Sygdomsintensivitet og -forl $\varnothing p$ var tydelig relatert til mengden av DMNA/kg l.v. helt uavhengig av applikasjonsmåten og medf $\varnothing$ rte hemorrhagiske centrolobulære nekroser og akutte karskader, spesielt i v. hepatica-systemet. Leverens regenerasjonsmulighet etter en enkelt dose DMNA er helt avhengig av karskadens intensivitet. Derfor kan et dyr tilsynelatende komme seg etter en akutt DMNA-påkjenning, men hvis karskaden i v. hepatica-systemet er stor nok, er karforandringene progredierende og fører til cirrhose i løpet av 3-4 mnd. Observasjonslengden av de enkelte rever etter engangseksponering har variert fra 13 til 380 dager og viser at $\mathrm{LD}_{50}$ ikke bør bestemmes etter overlevning ved 3 dager, men heller ved 4 uker eller mer. I vårt materiale er $\mathrm{LD}_{50}-10 \mathrm{mg}$ DMNA/kg l.v.

Ved å gi DMNA i fóret 2 ganger ukentlig etter en beregnet dagsdose av henholdsvis $1-0.2-0.1 \mathrm{mg} / \mathrm{kg}$ l.v. til 3 forskjellige grupper med tilsammen $18 \mathrm{dyr}$, fikk revene i de 2 f $\varnothing$ rste gruppene ikterus, ascites og leversvikt etter å ha fått i seg ca 45—75 mg DMNA/kg l.v. 
I gruppen med $1.0 \mathrm{mg}$ DMNA/kg l.v./dag fikk dyrene hemorrhagiske, centrolobulære levernekroser og produktive karforandringer $i$ vena hepatica. Revegruppen på $0.2 \mathrm{mg}$ DMNA/kg l.v./dag fikk også centrolobulære nekroser som etterhvert helet med fibrose og dyrene utviklet cirrhose og kronisk karfortykkelse og -forsnevring i v. hepatica-systemet, samt dannelse av små knuter bruskformasjoner og hematopoetisk vev, og en begynnende multipel tumordannelse av hemangiomat $\varnothing \mathrm{s}$ natur. Den minste DMNA dose $0.1 \mathrm{mg} / \mathrm{kg}$ l.v./dag bevirket ikke centrolobulære levernekroser, men f $\varnothing$ rte etter lengre tids eksponering til karfortykkelser i v. hepatica-systemet. De multiple hemangiosarkomer som ble utviklet $i$ leveren etter $3 \frac{1}{2}-4$ års DMNA eksponering fantes som regel i tilknytning til forandrede hepaticakar.

I et korttidsfors $\varnothing \mathrm{k}$ med opptil $0.13 \mathrm{mg}$ DMNA/kg l.v. i dagsfóret, fikk en ikke utviklet levernekroser, men kun mindre karforandringer i v. hepatica-systemet. Karforandringene ved DMNA-påvirkning angår tydeligvis ikke bare v. hepaticakarene, men også kroppens andre kar. Hematomer ble ofte påvist i rever som døde etter en enkelt dose DMNA. En av revene i fors $\varnothing$ ket d $\varnothing$ de av hjerneblødning, og kroniske karforandringer påvistes $i$ hjerte og nyrer på flere dyr. Disse funn viser at DMNA gir generelle karforandringer.

(Received September 21, 1981).

Reprints may be requested from: N. Koppang, the National Veterinary Institute, P.O. Box 8156, Dep, Oslo 1, Norway. 